\title{
Radiocarbon ages of pre-bomb clams and the hard-water effect in Lakes Michigan and Huron
}

\author{
David K. Rea ${ }^{1}$ \& Steven M. Colman ${ }^{2}$ \\ ${ }^{1}$ Department of Geological Sciences, The University of Michigan, Ann Arbor MI 48109-1063 \\ ${ }^{2}$ United States Geological Survey, Woods Hole, MA 02543
}

Received 16 August 1994; accepted 16 September 1994

\begin{abstract}
Five radiocarbon ages, all determined by accelerator mass spectrometry, have been obtained for two pre-bomb bivalves from Lake Michigan and one from Lake Huron. After correcting those ages for the fractionation of ${ }^{14} \mathrm{C}$ in calcite and for the radioactively inert $\mathrm{CO}_{2}$ in the atmosphere, we find residual ages, caused by the hard water effect, of about 250 years for Lake Michigan and 440 years for Lake Huron.
\end{abstract}

\section{Introduction}

In the course of conducting our research projects on the paleolimnology of the Great Lakes over the past several years we have had occasion to generate radiocarbon ages on the calcite of small bivalves found in the lacustrine sediments (Colman et al., 1990; 1994a, 1994b; Rea et al., 1994a, 1994b). The several ages that we have obtained, along with numerous other ages presented by prior investigators (see the compilation in Lewis \& Anderson, 1989) form an important data base for the interpretation of latest Quaternary and Holocene climate changes in the North American mid-continent. Most ages are on organic material, seeds, sticks and gyttja; some are on calcite. Investigators have been wary of calcite ages, even those made on discrete shell material, because the bicarbonate reservoir in any lake is formed from a combination of dissolved atmospheric $\mathrm{CO}_{2}$ and old carbon dissolved from limestone and dolomite in the rocks and sediments of the lake basin. Thus radiocarbon ages of calcite formed in natural waters may be too old by some unknown amount that represents the disequilibrium between the bicarbonate reservoir and the atmosphere, or the percentage of radioactively-inert carbon contributing to the dissolved bicarbonate (Broecker \& Walton, 1959; Benson, 1993; Mayle et al, 1993). Errors in ${ }^{14} \mathrm{C}$ dates on lacustrine calcite caused by this reservoir effect, commonly known as the hard-water effect (HWE), may be on the order of many hundreds of years (Colman et al., 1990). Because important events in the histories of Lakes Huron and Michigan may be separated by only hundreds of years and dated using both organic carbon and calcite samples, errors and corrections to ${ }^{14} \mathrm{C}$ ages derived from calcite are of critical importance.

\section{Determination of the hard-water effect}

In order to quantify the HWE in the ${ }^{14} \mathrm{C}$ ages of our materials, we have obtained accelerator-massspectrometer (AMS) radiocarbon ages on mollusk shells of known ages (Table 1). These shells were collected alive before the addition of ${ }^{14} \mathrm{C}$ to the atmosphere by nuclear explosions. Pieces of the same pre-bomb bivalve collected from Lake Michigan at Winnetka, north of Chicago, in 1937 were sent to three different laboratories at the University of Arizona, Lawrence Livermore National Laboratories, and the University of Toronto, as a blind check on their procedures. A fourth age on a Lake Michigan shell collected in 1940 was determined by the AMS laboratory at the Woods Hole Oceanographic Institution. One pre-bomb shell from Lake Huron, collected in 1908 along the south shore of Saginaw Bay, was also dated.

These AMS $-{ }^{14} \mathrm{C}$ dates (Table 1) are too old for three reasons. First is the hardwater effect which we are trying to define. Secondly, the industrial revolution has 
Table 1. Radiocarbon dates from modern bivalve shells from Lakes Michigan (M) and Huron (H)

\begin{tabular}{lllll}
\hline Shell & Location (lake) & Collection date & ${ }^{14}$ C-AMS age & Lab and Sample I.D. \\
\hline SB & Saginaw Bay (H) & 1908 & $655 \pm 45$ & Arizona, AA-11504 \\
BI & Beaver Island (M) & 1940 & $455 \pm 60$ & WHOI, OS-934 \\
W-1 & Winnetka (M) & 1937 & $450 \pm 70$ & LLNL, CAMS-8194 \\
W-2 & Winnetka (M) & 1937 & $500 \pm 45$ & Arizona, AA-11780 \\
W-3 & Winnetka (M) & 1937 & $490 \pm 40$ & Toronto, TO-4133 \\
\hline
\end{tabular}

Table 2. Determination of the hard water effect. HWE is the apparent age imparted to calcite of zero age because of the amount of inert carbon in the $\mathrm{HCO}_{3}^{-}$reservoir in the lake

\begin{tabular}{lllllll}
\hline Sample & $\begin{array}{l}\text { Pre-1950 } \\
\text { 'true' age }\end{array}$ & ${ }^{14} \mathrm{C}$ date & $\delta^{13} \mathrm{C}$ & $\begin{array}{l}\delta^{13} \mathrm{C} \\
\text { Corr'n }\end{array}$ & $\begin{array}{l}\text { inert } \mathrm{CO}_{2} \\
\text { corr'n }\end{array}$ & HWE \\
\hline SB & $44 \mathrm{y}$ & $655 \pm 45 \mathrm{y}$ & $-8.45 \% 0$ & $-142 \mathrm{y}$ & $-31 \mathrm{y}$ & $438 \pm 45 \mathrm{y}$ \\
$\mathrm{BI}$ & $11 \mathrm{y}$ & $455 \pm 60 \mathrm{y}$ & $-3.5 \% 0$ & $-57 \mathrm{y}$ & $-150 \mathrm{y}$ & $237 \pm 60 \mathrm{y}$ \\
$\mathrm{W}-1$ & $14 \mathrm{y}$ & $450 \pm 70 \mathrm{y}$ & $-3.2 \% 0$ & $-53 \mathrm{y}$ & $-134 \mathrm{y}$ & $249 \pm 70 \mathrm{y}$ \\
$\mathrm{W}-2$ & $14 \mathrm{y}$ & $500 \pm 45 \mathrm{y}$ & $-3.2 \% 0$ & $-54 \mathrm{y}$ & $-134 \mathrm{y}$ & $298 \pm 45 \mathrm{y}$ \\
$\mathrm{W}-3$ & $14 \mathrm{y}$ & $490 \pm 40 \mathrm{y}$ & $-3.2 \% 0$ & $-54 \mathrm{y}$ & $-134 \mathrm{y}$ & $288 \pm 40 \mathrm{y}$ \\
\hline
\end{tabular}

added radioactively-inert carbon dioxide to the atmosphere. This effect is responsible for a considerable offset in the apparent age of young materials (cf: Stuiver \& Quay, 1981). Stuiver \& Pearson (1993) provide a calibration to the radiocarbon timescale from dated tree rings that can be used to determine the apparent age effect of the inert $\mathrm{CO}_{2}$, approximately 30 years in 1908,135 years in 1937, and 150 years in 1940. The final cause of error is the fractionation of ${ }^{14} \mathrm{C}$ during the precipitation of calcite. This effect is quantified by measuring the $\delta^{13} \mathrm{C}$ of the shell and knowing the relationship between the fractionation of ${ }^{13} \mathrm{C}$ and ${ }^{14} \mathrm{C}$. The resultant age correction of the shell was determined using the relationships given by Taylor (1987).

Radiocarbon ages are given by convention in 'years before present', with 'present' defined as the year 1950. After correcting for the inert $\mathrm{CO}_{2}$ and carbon fractionation effects, the error we want to determine is the apparent age difference from 1950. Determination of this error, which is the hard-water effect, is shown in Table 2 and assumes no contamination or other unknown errors. The shell collected from Saginaw Bay in Lake Huron in 1908 was three or four years old and so should have a ${ }^{14} \mathrm{C}$ age of $44 \mathrm{yr}$. Carbon- 13 analyses of this shell average $-8.45 \%$ so the carbon fractionation correction is $-142 \mathrm{yr}$. The inert $\mathrm{CO}_{2}$ effect in
$1904-1907$ is 31 yr. The result is an age offset due to the HWE for the Lake Huron clam of 655 - 44 - 142 - 31 years or $438 \pm 45$ years (Table 2), a correction that has been applied to our radiocarbon ages on calcite from northern Lake Huron and Georgian Bay (Rea et al., 1994a).

For Lake Michigan we have averaged the hard water corrections determined from the single date on the 1940 bivalve $(237 \pm 60 \mathrm{yr})$ and the average value derived from three dates on the 1937 bivalve $278 \pm 52 \mathrm{yr}$ ). The resulting HWE is $257 \pm 56$ years, which we round to 250 years and apply to the ${ }^{14} \mathrm{C}$ dates on calcite from Lake Michigan (Colman et al., 1994a, 1994b).

\section{Discussion}

These distinctly different age offsets, like the different $\delta^{18} \mathrm{O}$ values for lake waters ( $-6 \%$ in Lake Michigan and $-7 \%$ in Lake Huron [Rea et al., 1994a]) indicate little mixing between the main volumes of the two lakes. Much of Lake Huron is rimmed by outcropping Paleozoic limestone and dolomite or till with a large carbonate mineral component. Dissolution of this carbonate detrital material (Graham \& Rea, 1980) likely 
is responsible for the much greater hard-water effect in that lake. Accordingly we have not averaged these values and corrected our Lake Huron dates using the Saginaw Bay correction (Rea et al., 1994a, 1994b) and our southern Lake Michigan dates using the Winnetka and Beaver Island corrections (Colman et al., 1994a, 1994b).

Documentation of a hard-water effect for Lake Huron which is $75 \%$ greater than that for Lake Michigan implies that all the Great Lakes may have different hard-water corrections. Although we cannot assume that the HWE has been constant with time, our calculations represent the best available estimate of that effect. We encourage all paleolimnologists relying on ${ }^{14} \mathrm{C}$ dates on calcite to repeat our experiment and date the modern (pre-bomb if possible) calcite in their study area at least twice.

\section{Acknowledgments}

We thank M. Kashgarian at Lawrence Livermore National Laboratory and R. Beukins at the Isotrace Laboratory of the University of Toronto for rapid responses to our requests for radiocarbon dates. M. Kashgarian, A. J. T. Jull of the TAMS facility at Arizona and G. A. Jones of the NOSAMS facility at Woods Hole answered questions about dating results and reservoir effects. D. Dettman helped us to penetrate the literature on corrections to radiocarbon dates. The Museum of Zoology at the University of Michigan provided the pre-bomb shells from Lake Michigan and Lake Huron. We thank D. J. Sauchyn for reviewing the manuscript. The first author was supported by NSF grant OCE-9101816. The TAMS facility at the University of Arizona and the NOSAMS facility at Woods Hole also receive support from the National Science Foundation.

\section{References}

Benson, L., 1993. Factors affecting ${ }^{14} \mathrm{C}$ ages of lacustrine carbonates: Timing and duration of the last highstand in the Lahontan Basin, Quaternary Research 39: 163-174.

Broecker, W. S. \& A. F. Walton, 1959. The geochemistry of ${ }^{14} \mathrm{C}$ in freshwater systems. Geochim. Cosmochim. Acta 16: 15-38.

Colman, S. M., G. A. Jones, R. M. Forester \& D. S. Foster, 1990. Holocene paleoclimatic evidence and sedimentation rates from a core in southwestern Lake Michigan. J. Paleolimnol. 4: 269-284.

Colman, S. M., R. M. Forester, R. L. Reynolds, D. S. Sweetkind, J. W. King, P. Gangemi, G. A. Jones, L. D. Keigwin \& D. S. Foster, 1994a. Lake-level history of Lake Michigan for the past 12000 years: The record from deep lacustrine sediments. J. Great Lakes Res. 20: 73-92.

Colman, S. M., L. D. Keigwin \& R. M. Forester, 1994b. Two episodes of meltwater influx from glacial Lake Agassiz into the Lake Michigan basin and their climatic contrasts. Geology 22: $547-550$.

Graham, E. J. \& D. K. Rea, 1980. Grain size and mineralogy of sediment cores from western Lake Huron. J. Great Lakes Res. 6: 129-140.

Lewis, C. F. M. \& T. W. Anderson, 1989. Oscillations of levels and cool phases of the Laurentian Great Lakes caused by inflows from the glacial Lakes Agassiz and Barlow-Ojibway. J. Paleolimnol. 2: $99-146$.

Mayle, F. E., A. J. Lavesque \& L. C. Cwynar, 1993. Acceleratormass-spectrometer ages for the Younger Dryas event in Atlantic Canada. Quat. Res. 39: 355-360.

Rea, D. K., T. C. Moore, Jr., C. F. M. Lewis, L. A. Mayer, D. Dettman, A. J. Smith \& D. M. Dobson, 1994a. Stratigraphy and paleolimnologic record of lower Holocene sediments in northern Lake Huron and Georgian Bay. Can. J. Earth Sci. 31: in press.

Rea, D. K., T. C. Moore, Jr., T, W. Anderson, C. F. M. Lewis, D. M. Dobson, D. L. Dettman, A. J. Smith \& L. A. Mayer, 1994b. Great Lakes paleohydrology: Complex interplay of glacial meltwater, lake levels and sill depths. Geology 22: 1059-1062.

Stuiver, M. \& G. W. Pearson, 1993. High-precision bidecadal calibration of the radiocarbon time scale, AD 1950-500 BC, and $2500-6000$ BC. Radiocarbon, 35: 1-23.

Stuiver, M. \& P. D. Qtay, 1981. Atmospheric ${ }^{14} \mathrm{C}$ changes resulting from fossil fuel $\mathrm{CO}_{2}$ release and cosmic ray flux variability. Earth Plan. Sci. Letters, 53: 349-362.

Taylor, R. E., 1987. Radiocarbon Dating: An Archeological Perspective. Academic Press, Orlando. 